\title{
Does Inclusive Education Change Teachers' Educational Goals? A Comparative Analysis of Two Cross-sectional Surveys in Austria
}

\author{
Susanne Schwab (Corresponding author) \\ Faculty of Educational Sciences, University of Bielefeld \\ Universitätsstrasse 25, 33615 Bielefeld, Germany
}

Tel: 49-521-106-4553Ｅ-mail: sussane.schwab@uni-bielefeld.de

Markus Gebhardt

School of Education, Technical University of Munich

Arcisstrasse 21, D-80333 Munich, Germany

Marco G.P. Hessels

Faculty of Psychology and Educational Sciences, University of Geneva Boulevard du Pont d'Arve, 40, CH-1205 Geneva, Switzerland

Barbara Ellmeier

Department of Education, Special Education Unit, University of Graz

Merangasse 70/II, A-8010 Graz, Austria

Sonja Gmeiner

Department of Education, Special Education Unit, University of Graz

Merangasse 70/II, A-8010 Graz, Austria

Peter Rossmann

Department of Education, Special Education Unit, University of Graz Merangasse 70/II, A-8010 Graz, Austria 
Received: Sep. 15, 2015 Accepted: Oct. 11, 2015 Published: November 1, 2015

http://dx.doi.org/10.5296/jse.v5i4.8310

URL: http://dx.doi.org/10.5296/jse.v5i4.8310

\begin{abstract}
This study analyses whether an increasing inclusion rate in Austria was accompanied by a change in teachers' educational goals and whether these goals were different for teachers in inclusive or non-inclusive settings. Educational goals were rated by 359 teachers in 1998 and 219 teachers in 2009. General pedagogical goals, as well as orientation on authority and discipline are considered less important by primary school teachers in inclusive classes than by those in schools without inclusion. The attitudes of teachers towards inclusion and teachers' estimates of the impact of inclusion of students with different types of disabilities were not correlated in 1998, but positively correlated in 2009 with the emphasis on the individuality of the students in the class, and not correlated in 1998, but negatively correlated in 2009 with the orientation on authority and discipline. It is concluded that a positive change can be observed.
\end{abstract}

Keywords: Special educational needs, inclusive education, teachers, educational goals, attitudes 


\section{Inclusive schooling in Austria}

A strong international trend towards inclusion in education has appeared since the UN-Convention on the Rights of Persons with Disabilities (Bürli 2009; Meijer 2010). Although the number of children with disabilities that are included in regular schools is rising in Europe, and in Austria in particular (e.g., Meijer 2010), the relatively slow increase of inclusion rates shows that most countries will probably need a number of years to achieve the goal of full inclusive education (European Agency 2009). The Austrian federal state of Styria has already been striving for inclusion since the 1990s and currently nearly $80 \%$ of the Styrian students with special educational needs (SEN) are taught in regular schools (Statistik Austria 2014).

Inclusive education in Austria is essentially characterised by classes taught by both a regular classroom teacher and a special needs teacher. The special needs teacher is mainly responsible for supporting the children with disabilities and ensures that they are adequately served in the inclusive classroom (Specht 1993; Specht, Gross-Pirchegger, Seel, Stanzel-Tischler, and Wohlhart 2006; Specht, Seel, Stanzel-Tischler, and Wohlhardt 2007). This is, of course, only a first step towards real inclusive schooling which requires continuous cooperative teaching. Experts consider the quality of teacher cooperation (regular and special needs teacher) an important indicator of the quality of teaching in inclusive settings (European Agency 2012), but it is also complex to fully realize (Friend, Cook, Hurley-Chamberlain, and Shamberger 2010). It is planned that the two-teacher system will also be implemented at the secondary level in the "new middle-schools" in Austria over the next few years (Gebhardt, Schwab, Gmeiner, Ellmeier, Rossmann, and Gasteiger-Klicpera 2013).

It should be emphasised that the term 'inclusion' is often understood differently, depending on the cultural background of a given country. In their review of the literature, Avramidis and Norwich (2002) have shown that the terms 'inclusion' and 'integration' are often used synonymously in scientific studies. In some American studies, 'inclusion' is simply understood as collective school attendance of children (of the same age) with and without disabilities (Reynolds and Fletcher-Janzen 2000). However, this corresponds rather with our understanding of 'integration' (Sander 2005). In the German-speaking areas in Europe, 'inclusion' is understood as an optimised form of 'integration' in which all children are regarded as individuals with different abilities, competences and needs, and all can profit from this diversity (Sander 2005). Since many classes in the Austrian educational system may be considered as 'inclusive', in which children with and without special needs are working and learning together, we decided to use the term 'inclusive education' in this article. Nonetheless, objectively speaking, Austrian children do not always find themselves in genuinely inclusive settings and providing effective inclusive education for all children remains an important challenge (see also Leeman and Volman 2000).

When children with special education needs are taught in regular schools, some basic conditions have to be ensured in order to achieve real inclusion. According to Reicher (2006), the number of students has to be reduced, team teaching is required, differentiated classroom 
management and curriculum permeability between school types and levels of education is needed. It also requires a didactic concept that meets the principles of joint and differentiated teaching (Feuser 1995; Heimlich 2004; see also Malvern and Skidmore, 2010) and the promotion of social skills becomes more important for teachers (Klicpera 1995). Furthermore, students' understanding of diversity and disability in the classroom should be fostered and, thus, systematic assistance should be available (Klicpera and Gasteiger-Klicpera 2004).

An interesting question is whether the placement of students with special education needs in inclusive classrooms leads to changes in educational practices in order to ensure successful teaching and learning for all students. The heterogeneous class composition and accompanying conditions for learning do not allow for a unified, classroom wide learning process. According to Ainscow, Booth, Dyson, Farrell, Frankham et al. (2006), inclusive education includes treating everyone equally, as well as meeting the needs of all individuals through differential treatment in order to take students' diversity into account (see also Feyerer and Prammer 2003). Consequently, inclusive education will require a high percentage of open and collaborative learning, such as working with a weekly schedule, varying learning situations, individualised instructions and discussion groups (Heimlich 2007). Moreover, inclusive education should not only be restricted to academic performance and individual characteristics of the student, but also social-cultural outcomes should be considered (Leeman and Volman 2000).

Feyerer (1998) showed that teachers in inclusive classes in the Austrian school pilot project changed their way of teaching, which had an effect on the students. Although the school achievements of students in inclusive and parallel classes were similar, the students in inclusive classes reported a better classroom climate and less pressure to perform. In a sample of 439 students, Gebhardt, Schwab, Krammer, Gasteiger-Klicpera, and Sälzer (2014) found that the principles of teaching that should prevail in inclusive classrooms were highly appreciated by the students. Especially the aspect of internal differentiation was generally evaluated more positively by students in inclusive classes than by those in regular classes. However, there were also inclusive classes in which, according to the reports of the students, little individualised education was found.

\section{Teachers' educational goals}

Over the last years, Austrian teachers have reported increasingly positive attitudes towards inclusion (Reicher 1988; Gebhardt, Schwab, Reicher, Ellmeier, Gmeiner, et al. 2011). As teachers in inclusive classes have to foster understanding of diversity and disability and educational support has to be planned systematically (Klicpera and Gasteiger-Klicpera 2004), teachers should change their educational goals in the classroom. According to Causton-Theoharis and Theoharis (2009), teachers must relinquish some of their traditional roles and must adopt new ones. This raised the question whether the rising inclusion rate in Austrian schools was accompanied by changing educational goal conceptions of teachers.

In the context of German empirical educational research, a special research tradition on 'educational goals' emerged in the 1960s and 1970s. A prominent study was presented by Krampen (1979), in which teachers were asked to rate the importance of various educational 
goals. The study showed that especially primary school teachers accorded a greater importance to educational goals in the area of social behaviour such as independence, helpfulness and freedom from anxiety or fear, than to performance-based goals such as logical thinking. Krampen's (1979) questionnaire for the assessment of teachers' goals included four subscales: 1) traditional pedagogical goals 2) orientation on authority and discipline, 3) striving for general appreciation and 4) emphasizing students' individuality. However, we interpreted the items of the first subscale (see Table 1) as more general educational goals that are likely to be relevant across different settings and educational context. The scale has been renamed accordingly. The scales are interesting in the context of inclusion, because there is good reason to believe that in times of growing inclusion, teachers will consider social goals of education (such as emphasizing students' individuality) to be more important and tend to move away from general educational goals, such as compliance with the curriculum requirements (Kalin and Zuljan 2007). A trusting relationship with the students and the promotion of autonomy and independence should also be important goals for teachers in inclusive settings. The relevance of these aspects has repeatedly been emphasised as important for inclusive education (see also Feyerer 1988; OECD 2010). The European Agency for Development in Special Needs Education emphasised the importance of individualization in inclusive teaching (more important than general educational goals) in the following way in its Special Needs Education Report: "Inclusion can be organised in several ways and on different levels, but essentially, it is the team of teachers who has to deal with an increasing diversity of student needs within their school and classes and has to adapt or prepare the curriculum in such a way that the needs of all students - those with SEN and their peers - are sufficiently met." (European Agency 2005, 13). Understanding of and adhering to inclusion by teachers implies that individualised and differentiated education will be the aim, even under non-optimal conditions (see also Jordan, Schwartz, and McGhie-Richmond 2009). However, in Austria and Germany, still separate curricula are used for students with and without SEN and although the teacher can choose which one will be used, the time for individual curricula for all students with and without SEN has not yet come. As for the orientation on authority and discipline of teachers, inclusion should rather lead to a respectful and attentive teacher-student contact, since this affects the development of learning (see also Altrichter, Trautmann, Wischer, and Doppler 2009). By contrast, preservation of the teacher's authority over the students tends to be more counterproductive. Already in 1939, Lewin, Lippitt and White demonstrated that this kind of preservation weakens work and group morale and could cause more conflicts between the students, which would be destructive regarding the concept of inclusion.

In 2009, indicators and basic principles for inclusive education in Europe were developed and proposed by the European Agency for Development in Special Needs Education, on the basis of recommendations by a group of international experts. As already mentioned, these experts considered the quality of the cooperation among teachers to be an important indicator of the quality of inclusive education (European Agency 2009). In this sense, not only a relationship of trust with the students, but also with the parents/caregivers has to exist, based on mutual respect and appreciation. 


\section{Aim of the study}

The present study aims at investigating changes in teachers' educational goals in relation to changes in inclusion rates in Austrian schools. Increasing inclusion necessarily leads to growing diversity in the classroom and, thus, students' individual needs will be much more dissimilar and distant from the regular school curriculum. This implies that teachers will have to adapt to this new situation and, consequently, are expected to adjust their educational goals.

Firstly, the educational goals of teachers in 2009 were evaluated, i.e., several years after the implementation of inclusive classes in Austria. Secondly, it was investigated whether the educational goals of teachers who work in inclusive settings differ from those who do not work in inclusive settings. We assume that teachers teaching in inclusive classrooms will rate the goals "Emphasizing students' individuality" and "Striving for appreciation on all sides" as more important than teachers who teach in regular or special school classes with a more homogenous class composition with regard to school performance. Conversely, they will ascribe a lower value to some of the "General pedagogical goals" and "Orientation on authority and discipline". Thirdly, as we also have survey data from a previous study executed in 1998, which is only shortly after inclusion was endorsed in Austrian law, we will examine whether teachers' goals have changed over the last decade by comparing the two cohorts. With the instauration of inclusive educational settings, individualization and cooperation with colleagues should have become more important. Furthermore, it is assumed that the importance of "Orientation on authority and discipline" and the adherence to "General pedagogical goals" have decreased. In addition, it is investigated whether a relationship exists between the educational goals of the teachers and their attitudes towards inclusive education. A review of the research literature by De Boer, Pijl, and Minnaert (2011) has shown that teachers generally hold a negative or neutral attitude towards the inclusion of students with special needs in regular primary education, but these attitudes have seem to become more positive during the last decade (Gebhardt et al. 2011; Schwab, Gebhardt, Tretter, Rossmann, Reicher et al. 2012). It is interesting to see whether these variables are also related to the teachers' educational goals.

\section{Method}

\subsection{Sample}

The data from Ellmeier (2002) were collected at the beginning of 1998 and included 359 teachers (334 females, 25 males). The sample comprised 61 teachers working in special schools, 63 teachers working in primary schools without inclusion, 75 teachers working in primary schools with inclusion (but not working in an inclusive class) and 160 teachers working in inclusive settings. Of the latter group, 100 were working as a primary school teacher or as integration teacher in inclusive classes and 60 were working as a primary school teacher or support teacher in support classes.

The survey by Gmeiner (2010) was conducted in June 2009. A total of 219 teachers (183 females, 30 males, 6 with unknown gender) were questioned. Of these 219 teachers, 14 


\section{Macrothink

teachers were working in special schools, 47 teachers were working in primary schools without inclusion, 64 teachers were working in primary schools with inclusion (but not working in an inclusive class), and 94 teachers were working in inclusive settings. Of the latter group, 50 were working as a primary school teacher or an integration teacher in integrated classrooms and 44 were working as a primary school teachers or a support teacher in support classes. Altogether the two samples consisted of 578 teachers, who were aged between 23 and 63 years $(\mathrm{M}=43.2, \mathrm{SD}=8.3)$.

\subsection{Material}

The teachers filled out the aforementioned questionnaire by Krampen (1979) assessing the importance of educational goals. The questionnaire comprises the following four subscales: 1) "General pedagogical goals", 2) "Orientation on authority and discipline", 3) "Striving for general appreciation" and 4) "Emphasizing students' individuality". The items of the scales are presented in Table 1.

Table 1. The four educational goals scales (adapted from Krampen, 1979)

\section{General pedagogical goals}

Observing curriculum requirements

Acting in line with professional scientific knowledge

Striving for absolute objectivity in student assessment

Encouraging the student's application and motivation

Promoting the student's idealism and commitment for higher goals

Educating the student to systematic reasoning

\section{Orientation on authority and discipline}

Maintaining the class discipline

Preserving authority towards the student

Challenging the student's ambition

Urging the student to discipline and orderliness

\section{Striving for personal appreciation on all sides}

Being appreciated by the student

Receiving respect and appreciation from colleagues

Receiving respect and appreciation from parents

\section{Emphasizing the students' individuality}

Establishing a trustful relationship with the student

Encouraging the student's independence and autonomy

Encouraging the student's self-esteem and confidence

Encouraging the student's creativity and imaginative behaviour

Educating the student to critical attitude

Educating the student to compassion and helpfulness

Educating the student to sincerity and honesty

Generating no fear in students 
The anchors of the 21 rating scale items were $0=$ unimportant, $1=$ rather unimportant, $2=$ rather important, 3 = important. The original items of Krampen (1979) were used, with one exception. The item "Striving for absolute objectivity" was accompanied by the words "in student assessment".

In addition to the educational goals, two scales were used to measure the teachers' attitudes to inclusion: "Attitude towards inclusive education" and the "Impact of inclusion on children without disabilities" (Reicher 1988). Both scales consist of eleven items with a four-point rating scale (anchors: $0=$ not true, and $3=$ true). The teachers had to respond to the items three times, but each time they had to take into account a different situation. The first presented the inclusion of students with a physical disability, the second presented the inclusion of students with a learning disability and the third presented the inclusion of students with an intellectual disability. Thus, each scale provided three measures and for each scale the average of the 11 items was computed. The scales, of which the psychometric characteristics were shown to be satisfactory, are discussed in detail elsewhere (Gebhardt et al. 2011; Schwab et al. 2012).

\section{Results}

\subsection{Educational goals}

Table 2 presents the means (M) and standard deviations (SD) of the five groups of teachers with regard to the four educational goals, for both cohorts (1998 and 2009) separately. First of all, it is striking that all values are relatively high (anchor 2 indicating "important" and 3 indicating "very important"). The scale "Emphasizing students' individuality", with group averages varying from 2.85 to 2.90 in 1998 and from 2.91 to 2.93 in 2009, seems to represent a particularly important educational goal, with high relevance for all teachers. However, also "General pedagogical goals" appear to play an important role with group means varying from 2.36 to 2.52 in 1998 and from 2.48 to 2.62 in 2009 . The "Orientation on authority and discipline" shows more divergence among teachers. In 1998 the means vary from 2.21 to 2.36 and in 2009 they vary from 2.35 to 2.67 . "Striving for general appreciation" is generally rated as of least importance, with group means varying from 1.92 to 2.17 in 1998 and means varying from 2.22 to 2.45 in 2009 .

A two-factorial multivariate analysis of variance was performed to examine whether the orientation on specific educational goals have changed from 1998 to 2009 and, particularly, whether different groups of teachers (special educational teachers, primary school teachers in primary schools without inclusion, teachers in primary schools with inclusion, teachers in inclusive classes/support classes) differed in terms of their goal orientations. The independent variables were the years of measurement and the groups of teachers.

The results showed a main effect of "Time", indicating that overall the scale means increased from 1998 to $2009\left(\mathrm{~F}_{4,523}=10.03, p<.01, \eta^{2}=.07\right)$. The univariate analysis further showed that this was true for all four scales of educational goal orientation: "General pedagogical goals", $\mathrm{F}_{1,526}=16.11, p<.01, \eta^{2}=.03$; "Orientation on authority and discipline", $\mathrm{F}_{1,526}=$ $25.89, p<.01, \eta^{2}=.05$; "Striving for general appreciation", $\mathrm{F}_{1,526}=23.55, p<.01, \eta^{2}=.04$; 
and "Emphasizing students' individuality", $\mathrm{F}_{1,526}=8.46, p<.01, \eta^{2}=.02$.

For the factor "teacher groups", the multivariate analysis was significant at the $10 \%$ level $\left(\mathrm{F}_{16,511}=1.57, p=.07, \eta^{2}=.01\right)$. Univariate analyses showed significant main effects for "teacher groups" in "Traditional pedagogical goals", $\mathrm{F}_{4,526}=3.27, p<.05, \eta^{2}=.02$; and "Orientation on authority and discipline", $\mathrm{F}_{4,526}=2.99, p<.05, \eta^{2}=.02$. Scheffés post hoc tests show that teachers in inclusive classes showed lower mean scores on these scales than primary school teachers in schools without inclusion.

Finally, no significant interaction effect was found $\left(\mathrm{F}_{16,526}=1.42\right.$, n.s. $)$.

Table 2. Means and standard deviations (min. $=0, \max .=3)$ in the various groups of teachers on the four pedagogical goals in 1998 and $2009^{\mathrm{a}}$.

\begin{tabular}{|c|c|c|c|c|c|}
\hline & & $\begin{array}{c}\text { General } \\
\text { pedagogical } \\
\text { goals }\end{array}$ & $\begin{array}{l}\text { Orientation on } \\
\text { authority and } \\
\text { discipline }\end{array}$ & $\begin{array}{l}\text { Striving for } \\
\text { general } \\
\text { appreciation }\end{array}$ & $\begin{array}{c}\text { Emphasizing } \\
\text { students' } \\
\text { individuality }\end{array}$ \\
\hline Groups of teachers & $N$ & $\mathrm{M}(\mathrm{SD})$ & $\mathrm{M}(\mathrm{SD})$ & $\mathrm{M}(\mathrm{SD})$ & $\mathrm{M}(\mathrm{SD})$ \\
\hline \multirow{2}{*}{$\begin{array}{l}\text { Special educational } \\
\text { teachers in special } \\
\text { schools }\end{array}$} & 57 & $2.30(.41)$ & $2.32(.49)$ & $2.15(.57)$ & $2.87(.19)$ \\
\hline & 13 & $2.58(.32)$ & $2.56(.27)$ & $2.36(.44)$ & $2.93(.11)$ \\
\hline \multirow{2}{*}{$\begin{array}{l}\text { Primary school } \\
\text { teachers in schools } \\
\text { without inclusion } \\
\text { experience }\end{array}$} & 57 & $2.52(.30)$ & $2.29(.42)$ & $1.96(.57)$ & $2.89(.19)$ \\
\hline & 41 & $2.62(.28)$ & $2.67(.35)$ & $2.45(.48)$ & $2.91(.16)$ \\
\hline \multirow{2}{*}{$\begin{array}{l}\text { Primary school } \\
\text { teachers in schools } \\
\text { with inclusion } \\
\text { experience }\end{array}$} & 69 & $2.47(.32)$ & $2.36(.54)$ & $2.07(.62)$ & $2.87(.20)$ \\
\hline & 61 & $2.58(.34)$ & $2.48(.47)$ & $2.28(.51)$ & $2.93(.15)$ \\
\hline \multirow{4}{*}{$\begin{array}{l}\text { Teachers in } \\
\text { inclusive classes } \\
\text { Teachers in support } \\
\text { teacher classes }^{b}\end{array}$} & 96 & $2.36(.37)$ & $2.21(.48)$ & $1.92(.57)$ & $2.90(.18)$ \\
\hline & 44 & $2.48(.36)$ & $2.35(.43)$ & $2.27(.54)$ & $2.93(.11)$ \\
\hline & 59 & $2.42(.33)$ & $2.25(.44)$ & $2.17(.53)$ & $2.85(.23)$ \\
\hline & 39 & $2.50(.35)$ & $2.53(.47)$ & $2.22(.51)$ & $2.93(.12)$ \\
\hline \multirow[t]{2}{*}{ Total } & 338 & $2.41(.36)$ & $2.28(.48)$ & $2.04(.58)$ & $2.88(.20)$ \\
\hline & 198 & $2.55(.33)$ & $2.51(.44)$ & $2.31(.51)$ & $2.93(.14)$ \\
\hline
\end{tabular}

${ }^{a}$ Values for 2009 in italics.

${ }^{\mathrm{b}}$ Includes both primary school and special school teachers

\subsection{Correlations between goal orientations and attitudes towards inclusion}

It was examined how the teachers' attitudes towards inclusion were related to the pedagogical values orientations. The correlations are presented in Table 3. As outlined previously, both the attitudes towards inclusion and the impact of inclusion had to be considered with three different conditions in mind: inclusion of a student with physical disability, inclusion of a student with learning disabilities and inclusion of a student with intellectual disabilities. 
Table 3. Correlations between educational goals and teachers' attitudes towards inclusion, respectively the impact of inclusion in 1998 and $2009^{\text {a }}$

\begin{tabular}{|c|c|c|c|c|c|c|}
\hline & \multicolumn{3}{|c|}{ Attitude towards inclusion of a } & \multicolumn{3}{|c|}{ Impact of inclusion of a } \\
\hline & $\begin{array}{c}\text { child with } \\
\text { physical } \\
\text { disabilities }\end{array}$ & $\begin{array}{c}\text { child with } \\
\text { learning } \\
\text { disabilities }\end{array}$ & $\begin{array}{l}\text { child with } \\
\text { intellectual } \\
\text { disabilities }\end{array}$ & $\begin{array}{c}\text { child with } \\
\text { physical } \\
\text { disabilities }\end{array}$ & $\begin{array}{c}\text { child with } \\
\text { learning } \\
\text { disabilities }\end{array}$ & $\begin{array}{l}\text { child with } \\
\text { intellectual } \\
\text { disabilities }\end{array}$ \\
\hline General & -.03 & -.03 & -.04 & -.09 & -.05 & -.06 \\
\hline $\begin{array}{l}\text { pedagogical } \\
\text { goals }\end{array}$ & $.11 *$ & .09 & .09 & .05 & .10 & .07 \\
\hline Orientation on & -.01 & -.01 & -.01 & -.03 & -.06 & -.04 \\
\hline $\begin{array}{l}\text { authority and } \\
\text { discipline }\end{array}$ & -.11 & $-.12 *$ & $-.14^{*}$ & -.10 & $-.11 *$ & $-.16^{*}$ \\
\hline Striving for & -.01 & .00 & -.01 & -.02 & -.03 & -.03 \\
\hline $\begin{array}{l}\text { general } \\
\text { appreciation }\end{array}$ & -.07 & -.08 & -.06 & -.03 & .01 & .04 \\
\hline Emphasizing & .02 & .11 & .07 & .01 & .10 & .12 \\
\hline $\begin{array}{l}\text { students' } \\
\text { individuality }\end{array}$ & $.22 *$ & $.24 * *$ & $.23 *$ & $.31 * *$ & $.31 * *$ & $.30^{* *}$ \\
\hline
\end{tabular}

a Sample sizes are smaller due to missing values: $\mathrm{N}=179$ in 1998 and $\mathrm{N}=328$ in 2009. Correlations for 2009 in italics.

$* * p \leq .01, * p \leq .05$

Table 3 shows that none of the correlations between attitudes of teachers towards inclusion of children with disabilities and the estimated impact of inclusion on other children in the classroom on the one hand and teachers' educational goals on the other, were significant in 1998. In contrast, in 2009 one can find several significant correlations between these variables. Positive significant correlations exist between all six attitude measures and the goal of "Emphasizing students' individuality". The more the attitude towards inclusion and the impact of the inclusions of a child with disabilities is rated positively, the more important the teachers consider the emphasis on students' individuality as an educational goal. The attitude towards the inclusion of a child with a physical disability shows a low correlation with "General pedagogical goals". Finally, some significant but relatively low negative correlations were found between teachers' attitudes towards inclusion and "Orientation on authority and discipline", except when the situation concerned children with physical disabilities (although the same tendency existed). This means that a more positive attitude is associated with a lower orientation on authority and discipline.

\section{Discussion}

The main question that was posed in this article was whether the changes in the Austrian school system, which is becoming more and more inclusive, was also accompanied by changes in teachers' educational goals. We based ourselves on the four educational goals proposed by Krampen (1979): "General pedagogical goals" (which was originally called "Traditional educational goals"), "Orientation on authority and discipline", "Striving for 
general appreciation" and "Emphasizing students' individuality". The high mean scores on each of the scales first of all show that teachers valued all four educational goals. Not only are the mean scores quite high, the scale means are also ordered in the same way from low to high in 1998 and 2009. Teachers put most emphasis on students' individuality. Not surprisingly, it is particularly important for teachers to establish a trusting relationship with the students, to encourage their self-reliance, independence, self-esteem, self-confidence, creativity and imaginative behaviour, as well as educating the students to a critical attitude, compassion, helpfulness and honesty, and avoiding creating anxiety among the students. The teachers largely agreed on this point. However, also the general educational goals, like sticking to curriculum requirements, striving for objectivity in assessing the students' performance, encouraging motivation, idealism and commitment, as well as educating students to systematic reasoning, appear to be well valued by teachers. Of course, factors like "educating students to systematic reasoning" and "encouraging motivation" may be considered as being relevant for all students. Especially the latter goal may be of particular importance for students with learning difficulties who often show decreased motivation due to repeated failure in learning (Hessels, Hessels-Schlatter, Bosson, and Balli 2009). Such goals are thus likely to be endorsed by many teachers at both time points and in various settings. The orientation on authority or discipline, e.g., maintaining discipline and preserving authority, is ranked third. Last, but still with relatively high values, is striving for general appreciation. Apparently, it is important for teachers to be appreciated by their students, but also to be respected and valued by colleagues and parents. Thus, it can be concluded that all four goals are highly relevant for teachers.

Secondly, the analyses of variance showed that the mean values of all four educational goals have increased over time. In contrast to our expectations, the largest increase (with the largest effect size) was observed for "Orientation on authority and discipline". It was presumed that, in the context of an increasingly inclusive education system in Austria, the orientation on authority and discipline would have decreased. The increasing mean score could be explained in different ways. First of all, it might be attributed to the inclusion of students with behaviour disorders. Students with challenging behaviours may put a high strain on the teachers and authority and discipline might be seen as strongly needed to cope with these students in the classroom. Secondly, the increased student diversity and the increasing demand for individuality (corroborated by the increased importance of "Emphasizing students' individuality") might have forced teachers to pay more attention to discipline in the classroom, in order to be able to implement individualised teaching. In this sense it might be argued that increasingly inclusive settings automatically create an increased need for maintaining discipline in order to teach effectively. However, as the orientation on authority and discipline was more pronounced among primary school teachers in schools without inclusion than among teachers in inclusive classes, one could argue that authority and discipline have become more important for all. In the research literature, too, school discipline seems to be an important topic (see e.g., MacAllister 2014). MacAllister even argues that school discipline should again become an important educational concept.

Also in contrast to our assumption, the "General educational goals" appeared to have become 
more important in 2009. This might be explained by the fact that, under the current renewed emphasis on educational standards and increasing school comparisons (such as PISA, PIRLS and TIMSS), teachers feel more and more personally evaluated and more and more pressure to perform (e.g., Barksdale-Ladd and Thomas, 2000; Moon, Brighton, Jarvis, and Hall 2007). The demands on teachers and school settings are constantly growing (see Reynolds 2001). In this sense teachers are required to show themselves confident that their goals are important. This might also explain why the means of all four educational goals increased over time.

In line with our hypothesis, the emphasis on students' individuality increased. Indeed, inclusive education has to secure successful learning for all students. The heterogeneous conditions for learning do not allow for learning processes that advance at the same pace for all students. Moreover, the primary goal of participation is achieved through individualization of instruction and differentiation within the classroom (Feyerer and Prammer 2003).

As might have been predicted, the importance of "Striving for general appreciation" also increased. Indeed, inclusive teaching requires close cooperation of teacher teams and such factors as receiving respect and appreciation from colleagues undeniably influence collaboration (see e.g. Gebhardt, et al. 2013).

It was further analysed whether pedagogical goals differ between the five groups of teachers. The comparisons showed that teachers in schools without inclusion more pursued the General educational goals than teachers working in inclusive settings. Furthermore, as already discussed, the orientation on authority and discipline was more pronounced among primary school teachers in schools without inclusion than among teachers in inclusive classes. Neither "Emphasizing the students' individuality", nor "Striving for general appreciation" showed any differences between the groups of teachers.

Lastly, the correlational analyses showed that the attitudes of teachers towards inclusive education and their pedagogical values orientations were completely unrelated in 1998. However, this has changed ten years later. In 2009 "Orientation on authority and discipline" was negatively related to four of the teachers' attitudes. The two correlations relating to the inclusion of a child with physical disabilities were not significant, but showed the same tendency. Furthermore, "Emphasizing students' individuality" now was positively related with all of the teachers' attitude scales. These results concur with the idea that increasing inclusion brings about a (positive) change in the pedagogical value orientations of teachers. Numerous studies underline the importance of these attitudes for their practical pedagogical work (see also e.g. Bless 1995; Butler 2012; de Boer et al. 2011; Eberwein and Knauer 2009). Also, as Jordan et al. (2008) rightly point out, teachers' inclusionary efficacy depends upon their beliefs about disabilities and their roles in working with students with special needs. The more they believe that these students are their responsibility, the more they are effective.

Summarising, it can be stated that the results of this study indicate that the advances with regard to inclusion in the Austrian school system over the past decade have been accompanied by a change in teachers' attitudes and especially that the relevance of pedagogical value orientations has increased during this period. Of course, we cannot make any causal inferences as many changes, both nationally and internationally, have taken place 
between 1998 and 2009 that may have influenced teachers' goals. We had, e.g., no information about the quality and the professional development received by those involved in inclusive classrooms. After all, in the 1990s, many studies warned of the need to prepare teachers professionally for inclusion (e.g., Rouse 2008; Schumm and Vaughn 1995a, 1995b). The special issue Preparing teachers to work in 'schools for all' (Florian 2009) further endorsed this by expressing the need to ensure that social and educational inclusion is included in teacher training (see also Florian and Rouse 2009). Even though our recent study on inclusive practices of general and special needs teachers (Schwab, Holzinger, Krammer, Gebhardt, and Hessels, submitted) showed that Austrian teachers hardly experience a need for training (except for training in dealing with challenging behaviour which seems to be the aspect that is most preoccupant for teachers), objectively speaking, teacher education in Austria does not (yet) fully prepare teachers for teaching students with special educational needs (see Abbott, McConkey, and Dobbins 2011; Sharma, Forlin, and Loreman 2008). Nevertheless, some of the results regarding educational goals and teachers' attitudes lead us to believe that a positive change can be observed.

\section{References}

Abbott, L., McConkey, R., \& Dobbins, L. (2011). Key players in inclusion: are we meeting the professional needs of learning support assistants for pupils with complex needs? European Journal of Special Needs Education, 26, 215-231. http://dx.doi.org/10.1080/08856257.2011.563608

Ainscow, M., Booth, T., Dyson, A., Farrell, P, Frankham, J., Gallannaugh, F., Howes, A., \& Smith, R. (2006). Improving schools, developing inclusion. London: Routledge.

Altrichter, H. Trautmann M., Wischer B., Sommerauer, S., \& Doppler B. (2009). Unterrichten in heterogenen Gruppen: Das Qualitätspotenzial von Individualisierung, Differenzierung und Klassenschülerzahl. [Teaching in heterogeneous groups: The potential quality of individualization.] In W. Specht (Ed.), Nationaler Bildungsbericht Österreich 2009. Band 2: Fokussierte Analysen bildungspolitischer Schwerpunktthemen. [National school report Austria 2009. Volume 2: Focused analyses of the main school policy themes.] Graz: Leykam.

Avramidis, E., \& Norwich, B. (2002). Mainstream teachers' attitudes towards inclusion/integration: a review of the literature. European Journal of Special Needs Education, 17, 1-19. http://dx.doi.org/10.1080/08856250210129056

Barksdale-Ladd, M.A., \& Thomas, K.F. (2000). What's at stake in high-stakes testing: Teachers and parents speak out. Journal of Teacher Education, 51, 384-397. http://dx.doi.org/ $10.1177 / 0022487100051005006$

Bless, G. (1995). Zur Wirksamkeit von Integration. Forschungsüberblick, praktische Umsetzung einer integrativen Schulform, Untersuchungen zum Lernfortschritt. [To working integration. Research overview, transformation of an integrative school type in practice, research on learning progress.] Bern: Haupt. 
Buchner, T., \& Gebhardt, M. (2011). Zur schulischen Integration in Österreich. [About school integration in Austria.] Zeitschrift für Heilpädagogik, 62, 298-304.

Bürli, A. (2009). Integration/Inklusion aus internationaler Sicht - einer facettenreichen Thematik auf der Spur. [Integration/inclusion from an international point of view - discovery of a many facetted theme]. In Bürli, A., Strasser U. \& Stein, A.-D. (Hrsg.), Integration/Inklusion aus internationaler Sicht. [Integration/inclusion from an international point of view]. Bad Heilbrunn: Klinkhardt.

Butler, R. (2012). Striving to connect: Extending an achievement goal approach to teacher motivation to include relational goals for teaching. Journal of Educational Psychology, 104, 726-742. http://dx.doi.org/10.1037/a0028613

Causton-Theoharis, J., \& Theoharis, G. (2009). Creating inclusive schools for all students. Education Digest: Essential Readings Condensed for Quick Review, 74, 43-47.

De Boer, A.A., Pijl, S.J., \& Minnaert, A.E.M.G. (2011). Regular primary school teachers' attitudes towards inclusive education: A review of the literature. International Journal of Inclusive Education, 15(3), 331-353. http://dx.doi.org/10.1080/13603110903030089

Eberwein, H., \& Knauer, S. (2009). Handbuch Integrationspädagogik. [Handbook of integration pedagogy]. Weinheim: Beltz.

Ellmeier, B. (2002). Schulische Integration behinderter Kinder: Einstellungen und berufliche Befindlichkeiten von Volks- und SonderschullehrerInnen. [School integration of children with disabilities: Attitudes and professional goals of teachers in primary and special education]. Unpublished doctoral dissertation. Graz, Austria: Karl-Franzens-Universität Graz.

European Agency (2005). Key principles for promoting quality in inclusive education. Retrieved from http://www.european-agency.org/agency-projects/key-principles/keyprinciples-files/Key-Principles-Matrix.pdf.

European Agency (2009). Entwicklung eines Satzes von Indikatoren für die inklusive Bildung in Europa. [Development of a set of indicators for inclusive education in Europe]. Retrieved from http://european-agency.org/publications/ereports/development-of-a-set-of-indicatorsfor-inclusive-education-in-europe/indicators-DE.pdf.

Feuser, G. (1995). Behinderte Kinder und Jugendliche zwischen Integration und Aussonderung. [Children and youngsters with disabilities between integration and segregation]. Darmstadt: Wissenschaftliche Buchgesellschaft.

Feyerer, E. (1998). Behindern Behinderte? Integrativer Unterricht auf der Sekundarstufe I. [Handicappping the handicaped? Joint teaching in secondary schools.] Innsbruck-Wien: Studienverlag.

Feyerer, E., \& Prammer, W. (2003). Gemeinsamer Unterricht in der Sekundarstufe I. Anregungen für eine integrative Praxis. [Joint teaching in secondary schools. Ideas for an integrative practice]. Weinheim; Berlin; Basel: Beltz. 
Gasteiger-Klicpera, B., Klicpera, C., Gebhardt, M., \& Schwab, S. (2012) Attitudes and Experiences of parents regarding inclusive and special school education for children with learning and intellectual disabilities. International Journal of Inclusive Education [Online]. http://dx.doi.org/10.1080/13603116.2012.706321.

Gebhardt, M., Schwab, S., Gmeiner, S., Ellmeier, B., Rossmann, P., \& Gasteiger-Klicpera, B. (2013). Grazer Skala zur LehrerInnenkooperation im integrativen Unterricht (GSLK). [Graz' scale for teacher cooperation in intregrative schooling]. Empirische Pädagogik, 27(1), 5-21.

Gebhardt, M., Schwab, S., Krammer, M., Gasteiger-Klicpera, B. \& Sälzer, C. (2014). Erfassung von individualisiertem Unterricht in der Sekundarstufe I. Eine Quantitative Überprüfung der Skala „Individualisierter Unterricht“ in zwei Schuluntersuchungen in der Steiermark. Zeitschrift für Bildungsforschung. http://dx.doi.org/10.1007/s35834-014-0095-7

Gebhardt, M., Schwab, S., Reicher, H., Ellmeier, B., Gmeiner, S., Rossmann, P., \& Gasteiger-Klicpera, B. (2011). Einstellungen von LehrerInnen zur schulischen Integration von Kindern mit einem sonderpädagogischen Förderbedarf in Österreich. [Attitudes of Austrian teachers towards integrative schooling of children with special education needs]. Empirische Sonderpädagogik, 4, 275-290.

Gmeiner, S. (2010). 20 Jahre später: Die Einstellung von LehrerInnen zur schulischen Integration in Österreich. [20 years after: The attitudes of Austrian teachers towards integration.] Unpublished Masterthesis, Graz, Austria: Karl-Franzens-Universität Graz. Retrieved from http://ema2.uni-graz.at:8090/livelinkdav2/nodes/272555/Gmeiner_Sonja\% 20Manuela\%2004.02.2010.pdf.

Heimlich, U. (2004). Didaktische Konzepte für den zieldifferenten Gemeinsamen Unterricht. [Didactical concepts for joint teaching with different goals]. Zeitschrift für Heilpädagogik, 55, $28-29$.

Heimlich, U. (2007). Gemeinsamer Unterricht im Rahmen inklusiver Didaktik. [Joint teaching in the context of inclusive didactics]. In U. Heimlich \& F. B. Wember (Hrsg.), Didaktik des Unterrichts im Förderschwerpunkt Lernen. Ein Handbuch für Studium und Praxis [Didactics for teaching. A handbook for study and practice]. (pp. 69-80). Stuttgart: Kohlhammer.

Klicpera, C. (1995). Behindertenintegration und die Situation der Lehrer. [Inclusion of people with disabilities and the context of the teacher]. In N. Severinski (Hrsg.), Gemeinsame Bildung Behinderter und Nichtbehinderter [Joint teaching of persons with and without disabilities]. (pp. 54-67). Höbersdorf: Kaiser.

Klicpera, C. \& Gasteiger-Klicpera, B. (2004). Erfahrungen der Eltern von Schülern mit geistiger Behinderung mit dem bisherigen Schulbesuch ihrer Kinder: Vergleich der Erfahrungen im integrativen Unterricht und in Sonderschulen. [Experiences with schooling by parents of children with disabilities: Comparing experiences in inclusive schools and special schools.] Zeitschrift für Heilpädagogik, 55, 270-278. 
Krampen, G. (1979). Erziehungsleitende Vorstellungen von Lehrern. [Educational ideas of teachers.] Zeitschrift für Experimentelle und Angewandte Psychologie, 26, 94-112.

Lewin, K., Lippitt, R., \& White, R. K. (1939). Patterns of aggressive behavior in experimentally created "social climates". Journal of Social Psychology, 10, 271-299.

Meijer, C. J. W. (2010). Special Needs Education in Europe: Inclusive Policies and Practices. Zeitschrift für Inklusion. Retrieved from http://www.inklusion-online.net/index.php/ inklusion/article/view/56/60.

Moon, T. R., Brighton, C. M., Jarvis, J. M., \& Hall, C. J. (2007). State standardized testing programs: Their effects on teachers and students (RM07228). Storrs, CT: The National Research Center on the Gifted and Talented, University of Connecticut.

OECD (2010). PISA 2009 Results: What Makes a School Successful? Resources, Policies and Practices (Volume IV). http://dx.doi.org/10.1787/9789264091559-en.

Reicher, H. (1988). Gemeinsam Lernen - Gemeinsam Leben: Die Einstellung von Eltern und Lehrern zur Integration behinderter Kinder in der Regelschule. [Learning together - Living together: Attitudes of parents and teachers towards integration of children with disabilities in mainstream classes.] Unpublished thesis. Vienna, Austria: Universität Wien.

Reicher, H. (2006). Sonderpädagogik-Integrationspädagogik-Inklusionspädagogik: Historische Entwicklungslinien und aktuelle Perspektiven. [Special education-iegrative education-inclusive education: Historical development and actual perspectives.] In A. Prettenthaler-Ziegerhofer (Hrsg.), Menschen mit Behinderung. Leben wie andere auch? [People with disabilities. Living like others?] (pp. 113-121). Graz: Grazer Universitätsverlag.

Reynolds, C. R., \& Fletcher-Janzen, E. (Eds.) $\left(2000,2^{\text {nd }}\right.$ Ed.). Encyclopedia of Special Education. New York: Wiley.

Sander, A. (2005). Bildungsstandards und Bildungsbarrieren: Thesen aus der Perspektive einer inklusiven Pädagogik. [Learning standards and learning barriers: Theses from the perspective of an inclusive pedagogy.] In U. Geiling \& A. Hinz (Eds.), Integrationspädagogik im Diskurs. Auf dem Weg zu einer inklusiven Pädagogik? [Integrative pedagogy in debate. Towards an inclusive pedagogy?] (pp. 110-113). Bad Heilbrunn, Germany: Klinkhardt.

Schumm, J.S., \& Vaughn, S. (1995a). Getting ready for inclusion: Is the stage set? Learning Disabilities Research and Practice, 10(3), 169-179.

Schumm, J.S., \& Vaughn, S. (1995b). Meaningful professional development in accommodating students with disabilities. Remedial and Special Education, 16(6), 344-353. http://dx.doi.org/10.1177/074193259501600604

Schwab, S., Gebhardt, M., Tretter, T., Rossmann, P., Reicher, H., Ellmeier, B., Gmeiner, S. \& Gasteiger-Klicpera, B. (2012). Auswirkungen schulischer Integration auf Kinder ohne Behinderung - eine empirische Analyse von LehrerInneneinschätzungen. Heilpädagogische Forschung, 2, 54-65. 


\section{Macrothink}

Journal of Studies in Education

ISSN 2162-6952

2015, Vol. 5, No. 4

Schwab, S., Holzinger, A., Krammer, M., Gebhardt, M., \& Hessels, M.G.P. (in press). Teaching practices and beliefs about inclusion of general and special needs teachers in Austria. Learning Disabilities: A Contemporary Journal.

Sharma, U., Forlin, C., \& Loreman, T. (2008). Impact of training on pre-service teachers' attitudes and concerns about inclusive education and sentiments about persons with disabilities. Disability and Society, 23, 773-85. http://dx.doi.org/10.1080/ 09687590802469271

Specht, W. (1993). Evaluation der Schulversuche zum gemeinsamen Unterricht behinderter und nichtbehinderter Kinder. Ergebnisse einer bundesweiten Befragung von Lehrerinnen und Lehrern im Schulversuch. Forschungsbericht. [Evaluation of joint schooling of children with and without disabilities. Results from a country-wide survey of teachers. Research report]. Graz, Austria: Zentrum für Schulversuche und Schulentwicklung, Abteilung II.

Specht, W., Gross-Pirchegger, L., Seel, A., Stanzel-Tischler, E., \& Wohlhart, D. (2006). Qualität in der Sonderpädagogik: Ein Forschungs- und Entwicklungsprojekt. Forschungsansatz, Ergebnisse, Schlussfolgerungen. [Quality in special education: a research and developmental project. Research plan, results, conclusions.] (ZSE-Report Nr. 70). Graz, Austria: Zentrum für Schulentwicklung.

Specht, W., Seel, A., Stanzel-Tischler, E., Wohlhart, D., \& die Mitglieder der Arbeitsgruppen des Projekts QSP. (2007). Individuelle Förderung im System Schule. Strategien für die Weiterentwicklung von Qualität in der Sonderpädagogik. [Individual teaching in the school system. Strategies for quality development in special education.] Graz-Klagenfurt, Austria: bifie.

Statistik Austria. (2010). Bildung in Zahlen: Tabellenband. [Schooling in numbers.] Vienna, Austria: Österreich GmbH. 